\title{
Effectiveness of iguratimod as monotherapy or combined therapy in patients with rheumatoid arthritis: a systematic review and meta-analysis of RCTs
}

Chao-Jun Hư ${ }^{\dagger}$, Li Zhang ${ }^{\dagger}$, Shuang Zhou, Nan Jiang, Jiu-Liang Zhao*, Qian Wang, Xin-Ping Tian and Xiao-Feng Zeng

\begin{abstract}
Background: This study aims to evaluate the efficacy and safety of the iguratimod (IGU) as monotherapy or combined therapy in patients with rheumatoid arthritis (RA) by using meta-analysis.

Methods: We searched Medline, EMBASE, Cochrane library, CNKI, Wanfang medical network from initial to 30 June, 2020, for randomized clinical trials (RCTs). Two authors independently screened the studies via reading the title, abstract, and full text. The risk of bias in individual studies was assessed using the Cochrane Risk of Bias tool. STATA 12.0 was used for pooled analysis of all included studies.

Results: A total of 23 RCTs were included in this analysis. Meta-analysis showed that patients in the IGU monotherapy or combined therapy group had significantly higher $\mathrm{ACR} 20(\mathrm{OR}=1.97,95 \% \mathrm{Cl} 1.29$ to $3.00, P=$ 0.002), lower DAS28-CRP (SMD $=-3.49,95 \% \mathrm{Cl}-5.40$ to $-1.58, P<0.001)$ and DAS28-ESR (SMD $=-2.61,95 \% \mathrm{Cl}$ -3.64 to $-1.57, P<0.001)$, as well as shorter duration of morning stiffness (SMD $=-2.06,95 \% \mathrm{Cl}-2.86$ to $-1.25, P<$ $0.001)$ and lower HAQ score (SMD $=-0.91,95 \% \mathrm{Cl}-1.61$ to $-0.21, P=0.011)$, than those received other diseasemodifying antirheumatic drugs (DMARDs) monotherapy (primarily comprising methotrexate). For the safety profile, IGU monotherapy had similar risks for gastrointestinal reactions $(P=0.070)$, leucopenia $(P=0.309)$, increment in transaminase $(P=0.321)$, increase of $\operatorname{ALT}(P=0.051)$, and liver damage $(P=0.182)$ to methotrexate monotherapy, and IGU combined with other DMARDs therapy did not increase the risks of these AEs $(P>0.05)$.
\end{abstract}

\footnotetext{
*Correspondence: zjlpumc@163.com

${ }^{\dagger}$ Chao-Jun Hu and Li Zhang are co-first authors.

Department of Rheumatology, Peking Union Medical College Hospital;

National Clinical Research Center for Dermatologic and Immunologic

Diseases (NCRC-DID); Key Laboratory of Rheumatology and Clinical

Immunology, Ministry of Education, Peking Union Medical College \& Chinese Academy of Medical Sciences, No. 1 Shuaifuyuan, Dongcheng District, Beijing 100730, China
}

(c) The Author(s). 2021 Open Access This article is licensed under a Creative Commons Attribution 4.0 International License, which permits use, sharing, adaptation, distribution and reproduction in any medium or format, as long as you give appropriate credit to the original author(s) and the source, provide a link to the Creative Commons licence, and indicate if changes were made. The images or other third party material in this article are included in the article's Creative Commons licence, unless indicated otherwise in a credit line to the material. If material is not included in the article's Creative Commons licence and your intended use is not permitted by statutory regulation or exceeds the permitted use, you will need to obtain permission directly from the copyright holder. To view a copy of this licence, visit http://creativecommons.org/licenses/by/4.0/ The Creative Commons Public Domain Dedication waiver (http://creativecommons.org/publicdomain/zero/1.0/) applies to the data made available in this article, unless otherwise stated in a credit line to the data. 
Conclusions: Our evidence suggests that IGU is effective and tolerant as monotherapy or combined therapy especially with methotrexate in patients with active RA. IGU may be regarded as a potential alternative to methotrexate, and a preferable choice when combined with other DMARDs for the treatment of RA.

Keywords: Iguratimod, Monotherapy, Combined therapy, Rheumatoid arthritis, Meta-analysis

\section{Background}

Rheumatoid arthritis (RA) is a chronic, inflammatory autoimmune disease, which is characterized by inflammation of synovial joints and cartilage erosion, leading to functional disability and increased risk of premature death [1]. Despite there being abundant drugs for treating RA, including conventional synthetic diseasemodifying antirheumatic drug (csDMARD), biologic DMARD (bDMARD), and targeted synthetic DMARD (tsDMARD), a considerable number of patients (about 20-30\%) still do not achieve remission or at least low disease activity [2]. The use of bDMARD and tsDMARD often result in rapid and sustained clinical remission for the majority of patients, while are also associated with the risk of adverse events (AEs), such as prolonged immunosuppression, infection, and economic implications $[3,4]$. Hence, csDMARD, ideally methotrexate, remains the basis of RA treatment in clinic, especially in lowincome countries. According to the 2019 EULAR recommendations, csDMARD are primarily used as induction and maintenance therapy for patients who receive initial treatment or have inadequate response to initial csDMARD monotherapy to reach the target of sustained remission [5]. For patients with persistent remission after bDMARD or tsDMARD therapy, tapering DDMARD or tsDMARD should be considered, and may be maintained with csDMARD [6]. Therefore, csDMARD plays a pivotal role in RA treatment.

Iguratimod (IGU), a novel small-molecule DMARD which has a unique mechanism of action compared with that of other DMARDs. As a novel immunomodulator, IGU act simultaneously on $\mathrm{T}$ and $\mathrm{B}$ lymphocytes to regulate the balance of immune cells and cytokines, such as T-bet, IL-17, STAT3, Bcl6, IL-21, IFN- $\gamma$, TNF- $\alpha$, and IL-17A [7]. IGU also has an anti-inflammatory role via inhibiting canonical inflammation-associated signaling pathways, such as NF- $\mathrm{kB}$ [8-11] and IL-17R pathway $[12,13]$. Moreover, IGU demonstrated anabolic effects on bone metabolism. IGU can increase the expression of osterix and Dlx5 to promote osteoblast differentiation [14], and inhibiting the expression of MMP-1, MMP-3 [15], and RANKL/OPG [16, 17] to suppress bone resorption.

There are amounts of studies on IGU monotherapy or combined therapy. Previous studies demonstrated that IGU monotherapy was non-inferior to methotrexate (MTX) in efficacy, but more tolerant than MTX [18]. In addition, several randomized controlled trials (RCTs) indicated that IGU plus MTX has also achieved better effectiveness than MTX monotherapy in patients with RA $[19,20]$. Consequently, in the 2015 Asia Pacific League of Associations of Rheumatology (APLAR) guideline, iguratimod was suggested as first-line treatment in the condition that patients who cannot tolerate MTX in some Asia-Pacific countries [21]. Moreover, the latest version of 2018 APLAR guideline also recommends the application of iguratimod as the 2015 version [22]. Iguratimod may be added to methotrexate to enhance efficacy when response to MTX monotherapy is inadequate [23].

A recently published meta-analysis evaluated the efficacy and safety of iguratimod monotherapy over other DMARDs [24]. Although amounts of evidences of IGU combined therapy have been accumulated, the efficacy and safety of IGU combined therapy have been poorly estimated. Therefore, this systematic review aims to comprehensively assess the efficacy and safety of IGU therapy (IGU monotherapy and combined therapy) for RA to provide more guidance of IGU use in the future.

\section{Methods}

\section{Literature search}

Two researchers searched the Medline, EMBASE, Cochrane library, CNKI, Wanfang medical network from initial to 30 June, 2020, and they reviewed the title, abstract, and even the full text at the same time to determine whether the study met the inclusion criteria independently. Search strategy for the PubMed database is given as follows: ((Iguratimod OR T-614 OR IGU) AND (rheumatoid arthritis OR RA)) AND (English[Language]).

\section{Inclusion and exclusion criteria}

The following criteria were adopted: (1) randomized control trials (RCTs) that evaluate the efficacy and safety of IGU monotherapy and IGU combined MTX therapy with MTX as a comparator drug, and the efficacy of IGU plus other DMARDs compared with other DMAR Ds monotherapy in treating patients with RA; (2) patients receiving a diagnosis of RA according to the 1987 American College of Rheumatology (ACR) or 2010 ACR/European League against Rheumatism (EULAR) RA classification criteria [25, 26]; and (3) there are no mixed intervention in the test group and control group. 
(4) One or more of the following outcomes were reported to allow data on to be extracted: American College of Rheumatology (ACR) 20, Disease Activity Score in 28 joints-C-reactive protein (DAS28-CRP), DAS28erythrocyte sedimentation rate (ESR), Health Assessment Questionnaire (HAQ) score, and duration of morning stiffness.

We excluded the following articles: (1) incomplete or duplicative data; (2) Chinese medicine in the combination group and/or the control group; (3) the control group was intervention with placebo; (4) patients with both RA and cancer, renal dysfunction, or other complications; (5) case reports, reviews, etc.

\section{Data extraction and quality assessment}

Two researchers read the full text of selected eligible studies at the same time, and extracted the following data from each study, including the author, title, year, design, outcome, and other specific values in the study. Methodological quality of the included studies was assessed using Cochrane Risk of Bias tool (version 5.1.0, updated in March 2011) which is developed for assessing the quality of RCTs. The Cochrane Risk of Bias tool included 6 domains: selection, performance, detection, attrition, reporting, and other bias [27].

\section{Statistical analysis}

The statistical analysis was performed by authors using STATA 12.0 (StataCorp LP, College Station, Texas).
Heterogeneity among the included studies was tested, and the size of heterogeneity was determined according to Cochran's Q statistic and the $I^{2}$ statistic. Low heterogeneity was defined as $25 \%<I^{2}<50 \%$; moderate heterogeneity was defined as $I^{2} \geq 50 \%$ and high heterogeneity was defined as $I^{2} \geq 75 \%$. According to the heterogeneity, fixed or random effect models were used between different studies. When there was no heterogeneity in the included studies, the fixed effects model was used for meta-analysis; otherwise, the random effects model was used, and $P<0.05$ was considered statistically significant. In addition, sensitivity analysis was performed to ensure the robustness of results, and the summarized odd ratio (OR) or standard mean difference (SMD) was analyzed with the omission of one study at a time to detect whether the overall results were strongly affected by a specific study. Publication bias was evaluated through Egger's linear regression and visual inspection of funnel plots.

\section{Results}

Study selection

We identified 571 citations and the detailed article search process was presented in Fig. 1. According to the inclusion and exclusion criteria, 23 selected articles involving 2533 patients were included in this analysis finally $[18-20,28-47]$. Three RCTs compared IGU monotherapy versus MTX monotherapy, 18 RCTs compared IGU plus MTX versus MTX monotherapy (7

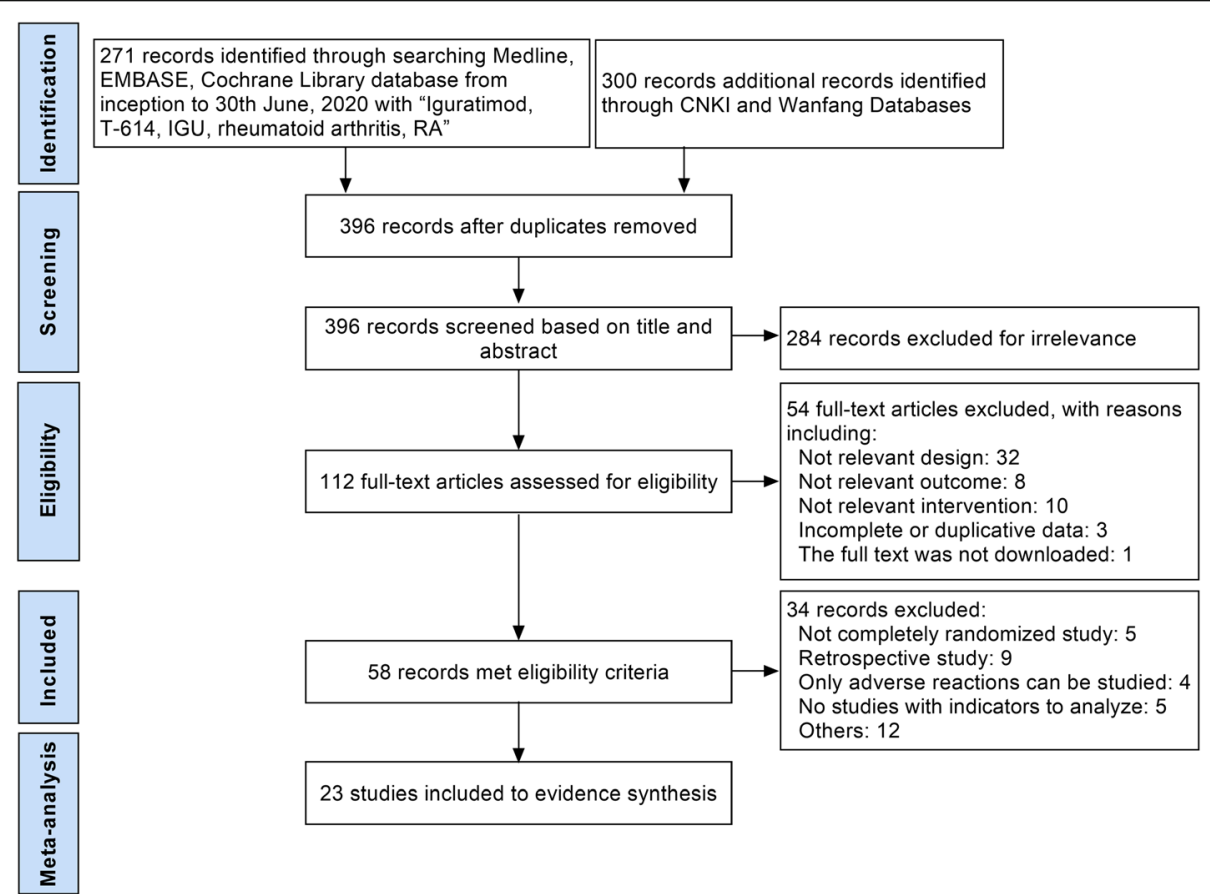

Fig. 1 Study selection flow diagram 
RCTs of them compared IGU plus MTX, MTX monotherapy and IGU monotherapy), 1 RCT compared IGU plus leflunomide versus leflunomide monotherapy, and 1 RCT compared IGU plus etanercept versus etanercept monotherapy. The duration of treatment ranged from 12 to 68 weeks, most of them were 24 weeks. ACR20 response, DAS28-CRP, DAS28-ESR, HAQ score, duration of morning stiffness, and adverse events were used to measure outcomes in $8,4,8,7$, studies respectively. Characteristics of included studies were listed in Table 1.

\section{Quality assessment}

As displayed in Fig. 2, random allocation was reported in all included studies, but only a few studies adopted random number table. Allocation concealment, blinding of participants and personnel, and blinding of outcome assessment for most studies were assessed as unclear

Table 1 Characteristics of included studies

\begin{tabular}{|c|c|c|c|c|c|}
\hline Study & $\begin{array}{l}\text { Participants, } \\
n\end{array}$ & RA type & Intervention & Duration & Outcomes \\
\hline Xia 2016 & 150 & Active RA & $\begin{array}{l}\text { IGU+MTX vs. IGU vs. } \\
\text { MTX }\end{array}$ & 24 weeks & $\begin{array}{l}\text { ACR20, ACR50, ACR70, DAS28-ESR, DAS28-CRP, duration of morning } \\
\text { stiffness, HAQ, adverse events. }\end{array}$ \\
\hline $\begin{array}{l}\text { Zhao } \\
2017\end{array}$ & 96 & Active RA & $\begin{array}{l}\text { IGU+MTX vs. IGU vs. } \\
\text { MTX }\end{array}$ & 24 weeks & ACR20, ACR50, ACR70, DAS28-CRP, HAQ, adverse events. \\
\hline Cao 2018 & 90 & Active RA & $\begin{array}{l}\text { IGU+MTX vs. IGU vs. } \\
\text { MTX }\end{array}$ & 24 weeks & DAS28-CRP, HAQ \\
\hline Xu 2015 & 110 & Active RA & $\begin{array}{l}\text { IGU+MTX vs. IGU vs. } \\
\text { MTX }\end{array}$ & 52 weeks & Duration of morning stiffness, adverse events. \\
\hline $\begin{array}{l}\text { Zhao } \\
2016\end{array}$ & 90 & Active RA & $\begin{array}{l}\text { IGU+MTX vs. IGU vs. } \\
\text { MTX }\end{array}$ & 24 weeks & ACR20, ACR50, ACR70, adverse events. \\
\hline $\begin{array}{l}\text { Xiong } \\
2015\end{array}$ & 86 & Active RA & IGU+MTX vs.IGU vs. MTX & 24 weeks & DAS28-ESR, adverse events. \\
\hline LV 2014 & 131 & Active RA & $\begin{array}{l}\text { IGU+MTX vs. IGU vs. } \\
\text { MTX }\end{array}$ & 24 weeks & DAS28-ESR, DAS28-CRP, duration of morning stiffness, HAQ \\
\hline $\begin{array}{l}\text { Duan } \\
2015\end{array}$ & 60 & Active RA & IGU+MTX vs. MTX & 24 weeks & ACR20, ACR50, ACR70, DAS28, HAQ, adverse events. \\
\hline $\begin{array}{l}\text { Ishiguro } \\
2013\end{array}$ & 252 & Active RA & IGU+MTX vs. MTX & 24 weeks & ACR20, ACR50, ACR70, HAQ, adverse events. \\
\hline Ren 2017 & 82 & Active RA & IGU+MTX vs. MTX & 26 weeks & Duration of morning stiffness, adverse events. \\
\hline $\begin{array}{l}\text { Wang } \\
2017\end{array}$ & 120 & Active RA & IGU+MTX vs. MTX & 68 weeks & DAS28-ESR, adverse events. \\
\hline Bai 2015 & 100 & Active RA & IGU+MTX vs. MTX & 24 weeks & ACR20, ACR50, adverse events. \\
\hline Xie 2018 & 120 & $\begin{array}{l}\text { Refractory } \\
\text { RA }\end{array}$ & IGU+MTX vs. MTX & 17 weeks & DAS28-ESR, adverse events. \\
\hline $\begin{array}{l}\text { Wang } \\
2016\end{array}$ & 87 & $\begin{array}{l}\text { Refractory } \\
\text { RA }\end{array}$ & IGU+MTX vs. MTX & 24 weeks & DAS28, adverse events. \\
\hline $\begin{array}{l}\text { Meng } \\
2016\end{array}$ & 60 & $\begin{array}{l}\text { Refractory } \\
\text { RA }\end{array}$ & IGU+MTX vs. MTX & 16 weeks & DAS28-ESR, adverse events. \\
\hline $\begin{array}{l}\text { Chen } \\
2018\end{array}$ & 120 & Active RA & IGU+MTX vs. MTX & 24 weeks & Duration of morning stiffness, adverse events. \\
\hline Xu 2017 & 83 & Active RA & IGU+MTX vs. MTX & 52 weeks & DAS28, adverse events. \\
\hline $\begin{array}{l}\text { Xiong } \\
2020\end{array}$ & 102 & Active RA & IGU+MTX vs. MTX & 24 weeks & Duration of morning stiffness, adverse events. \\
\hline Lu 2009 & 326 & Active RA & IGU vs. MTX & 24 weeks & $\begin{array}{l}\text { ACR20, ACR50, ACR70, duration of morning stiffness, HAQ, adverse } \\
\text { events. }\end{array}$ \\
\hline $\begin{array}{l}\text { Yang } \\
2017\end{array}$ & 60 & Active RA & IGU vs. MTX & 12 weeks & DAS28-ESR, duration of morning stiffness. \\
\hline Hu 2014 & 40 & Active RA & IGU vs. MTX & 24 weeks & ACR20, DAS28-ESR, adverse events. \\
\hline Dai 2019 & 108 & Active RA & $\begin{array}{l}\text { IGU+Leflunomide vs. } \\
\text { Leflunomide }\end{array}$ & 12 weeks & DAS28-3, duration of morning stiffness, adverse events. \\
\hline Li 2018 & 60 & $\begin{array}{l}\text { Refractory } \\
\text { RA }\end{array}$ & $\begin{array}{l}\text { IGU+ Etanercept vs. } \\
\text { Etanercept }\end{array}$ & 12 weeks & DAS28-ESR, adverse events. \\
\hline
\end{tabular}




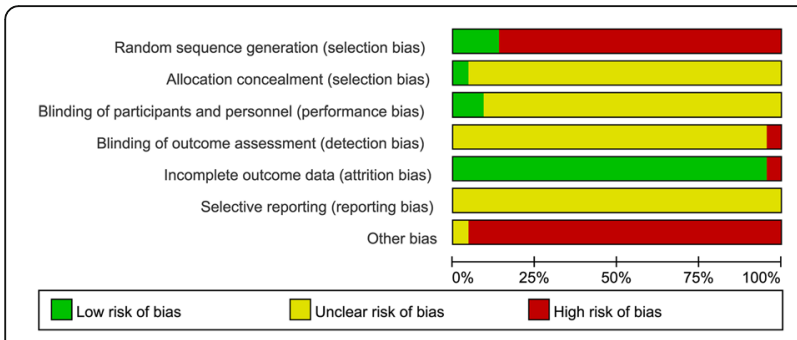

Fig. 2 Methodological quality of included studies in the meta-analysis

risk due to the related data was not described. All studies had low risk of incomplete outcome, while the risk of other bias was assessed as high.

\section{Efficacy}

The overall pooled analysis of ACR20 response was displayed in Fig. 3. We found that IGU therapy was associated with a significant increase of ACR20 response (OR $=1.97,95 \%$ CI 1.29 to $3.00, P=0.002$ ), compared with the MTX monotherapy. Subgroup analysis based on different comparisons indicated that there was no statistically significant difference between IGU monotherapy and MTX monotherapy (OR $=1.19,95 \%$ CI 0.85 to1.66, $P=0.322)$. While ACR20 response was significantly higher in patients treated with IGU plus MTX therapy compared to patients treated with MTX monotherapy $(\mathrm{OR}=3.10,95 \% \mathrm{CI} 2.04$ to $4.70, P<0.001)$. Patients with the IGU therapy have significantly lower DAS28-CRP $(\mathrm{SMD}=-3.49,95 \% \mathrm{CI}-5.40$ to $-1.58, P<0.001$; Fig. 4$)$ and DAS28-ESR (SMD $=-2.61,95 \% \mathrm{CI}-3.64$ to $-1.57, P$ $<0.001$; Fig. 5) than those with other DMARDs monotherapy (primarily comprising MTX). The result of subgroup analysis showed that DAS28-CRP and DAS28-ESR exhibited a marked decline in patients treated with IGU monotherapy (DAS28-CRP: SMD $=-1.95,95 \% \mathrm{CI}-3.82$ to $-0.08, P=0.041$; DAS28-ESR: SMD $=-1.40,95 \% \mathrm{CI}$ -2.62 to $-0.19, P=0.023)$; and IGU combined with MTX therapy (DAS28-CRP: SMD $=-5.21,95 \% \mathrm{CI}-9.61$ to $-0.82, P=0.020$; DAS28-ESR SMD $=-4.05,95 \%$ CI -6.14 to $-1.96, P<0.001)$ compared to patients treated with MTX monotherapy (Figs. 4 and 5). For the comparison of IGU plus etanercept versus etanercept monotherapy, only 1 study reported DAS28-ESR [46]. IGU plus etanercept had lower DAS28-ESR than etanercept monotherapy $(\mathrm{SMD}=-1.22,95 \% \mathrm{CI}-1.77$ to $-0.66, P<0.001)$.

Further analyzing other related symptoms of RA, we found that treatment of IGU therapy significantly reduced the duration of morning stiffness $(\mathrm{SMD}=-2.06$, $95 \% \mathrm{CI}-2.86$ to $-1.25, P<0.001$; Fig. 6$)$ and the HAQ score $(\mathrm{SMD}=-0.91,95 \% \mathrm{CI}-1.61$ to $-0.21, P=0.011$;

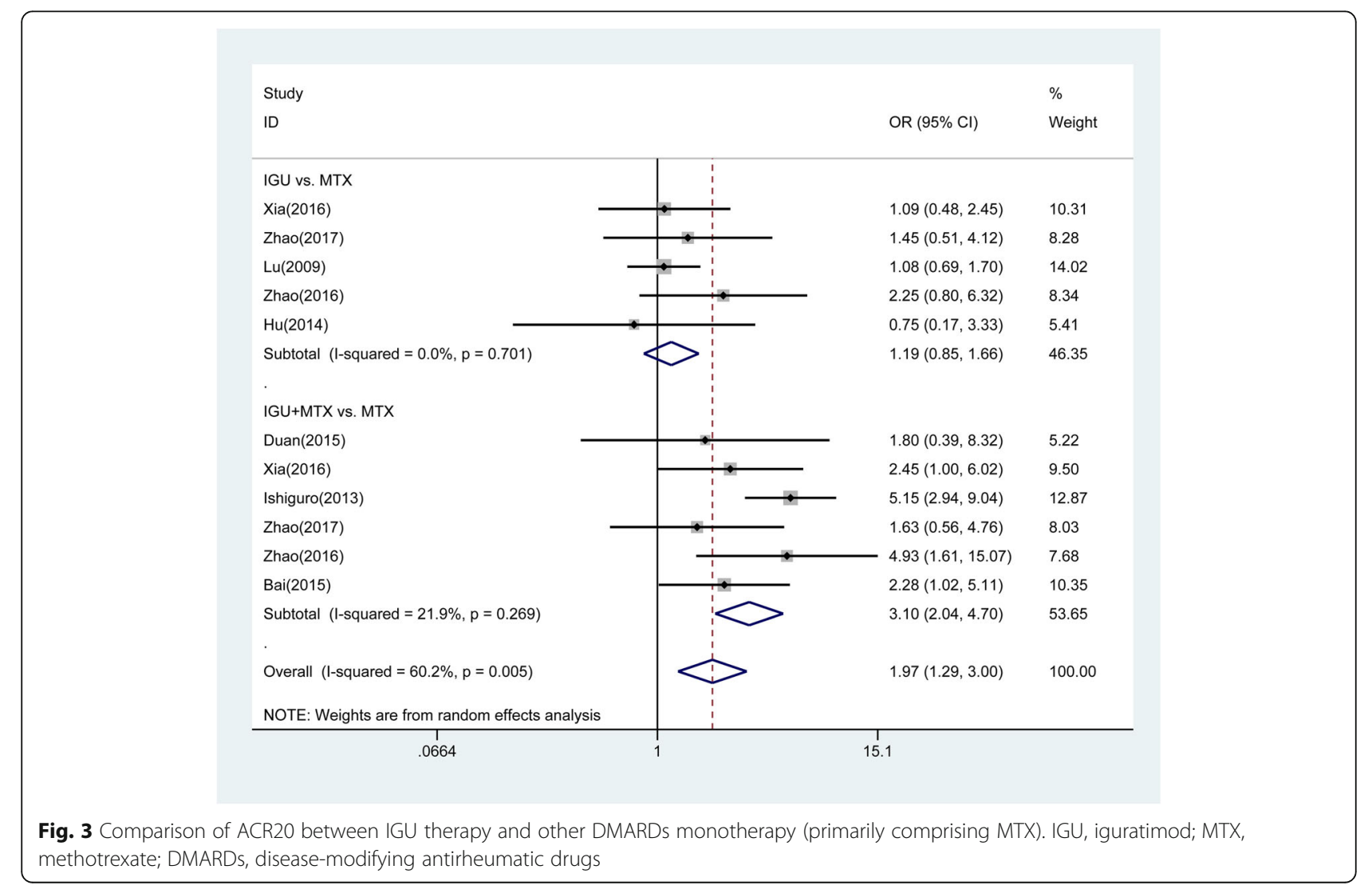




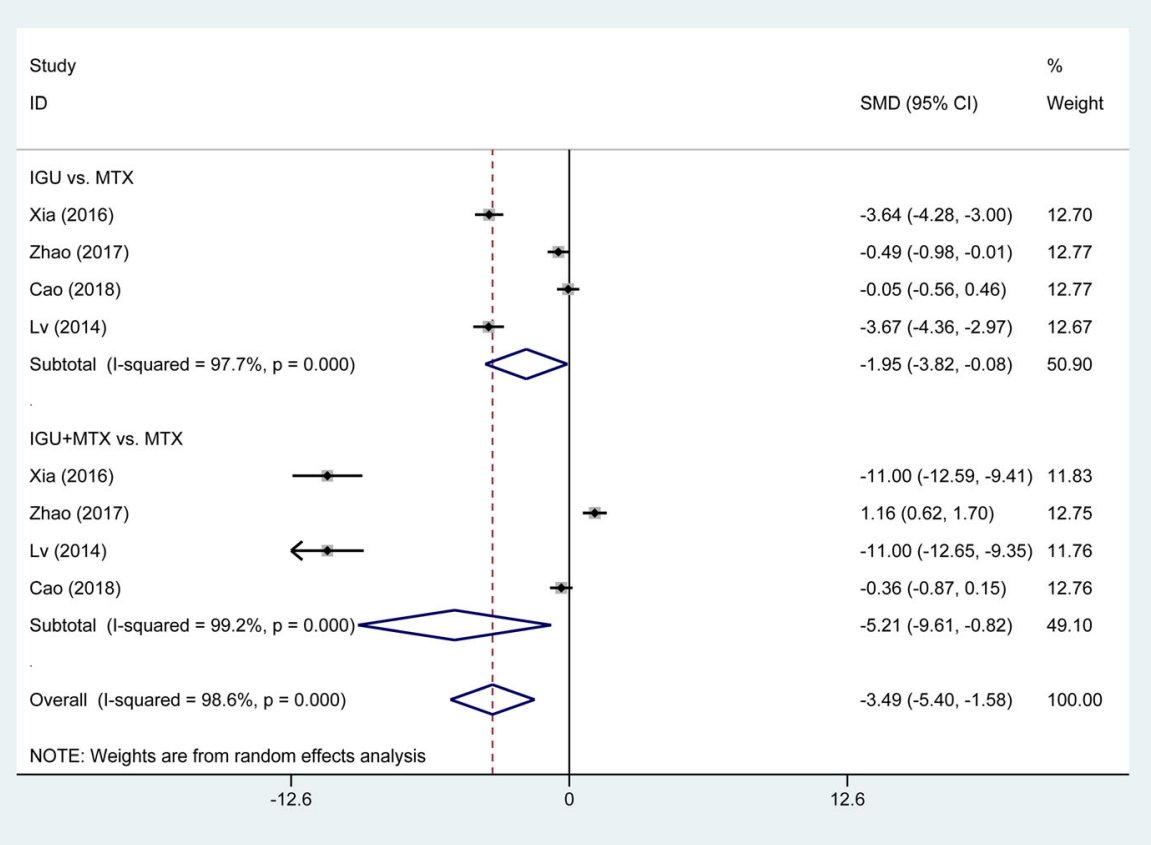

Fig. 4 Comparison of DAS28-CRP between IGU therapy and other DMARDs monotherapy (primarily comprising MTX). IGU, iguratimod; MTX, methotrexate; DMARDs, disease-modifying antirheumatic drugs

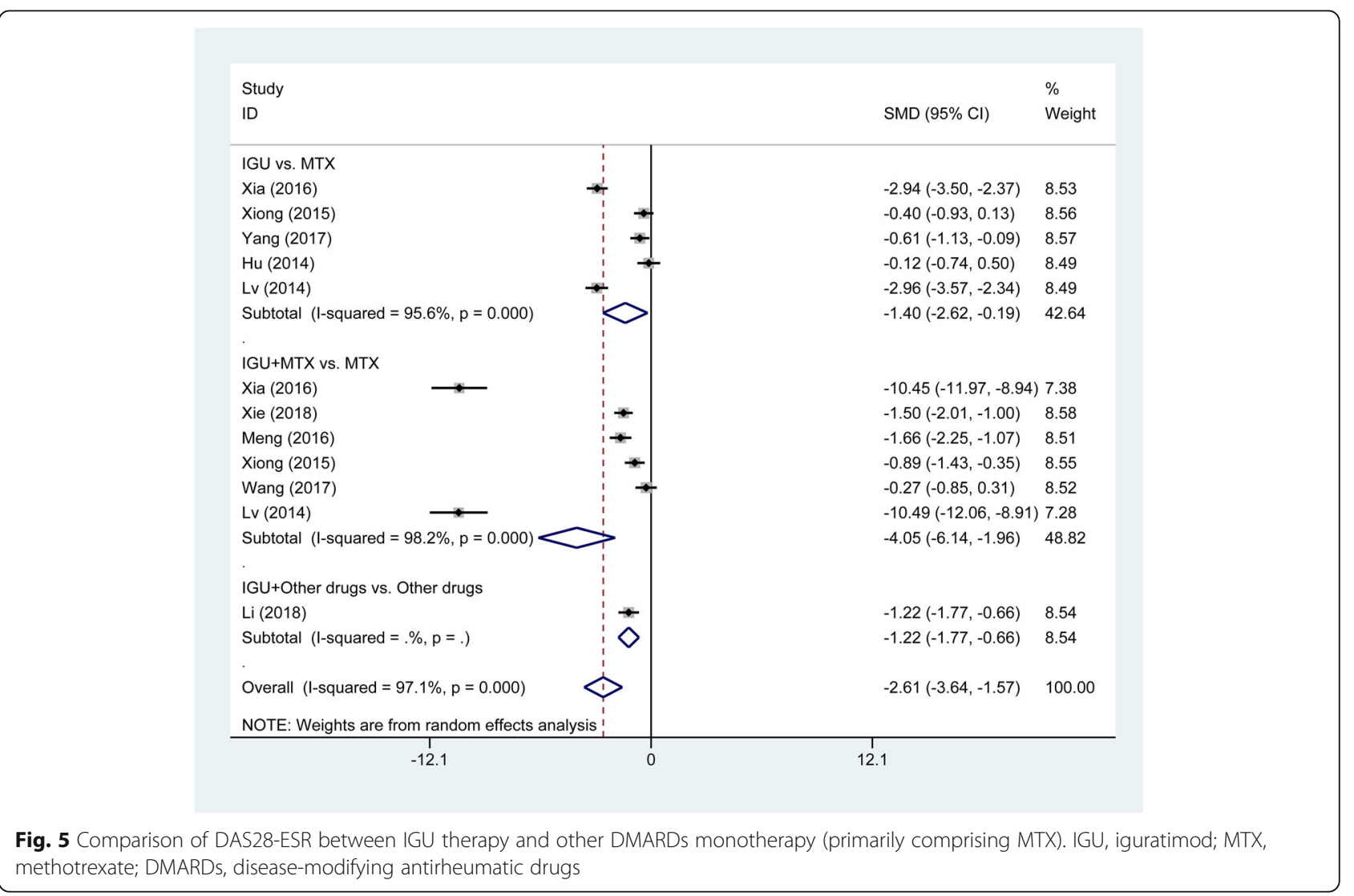




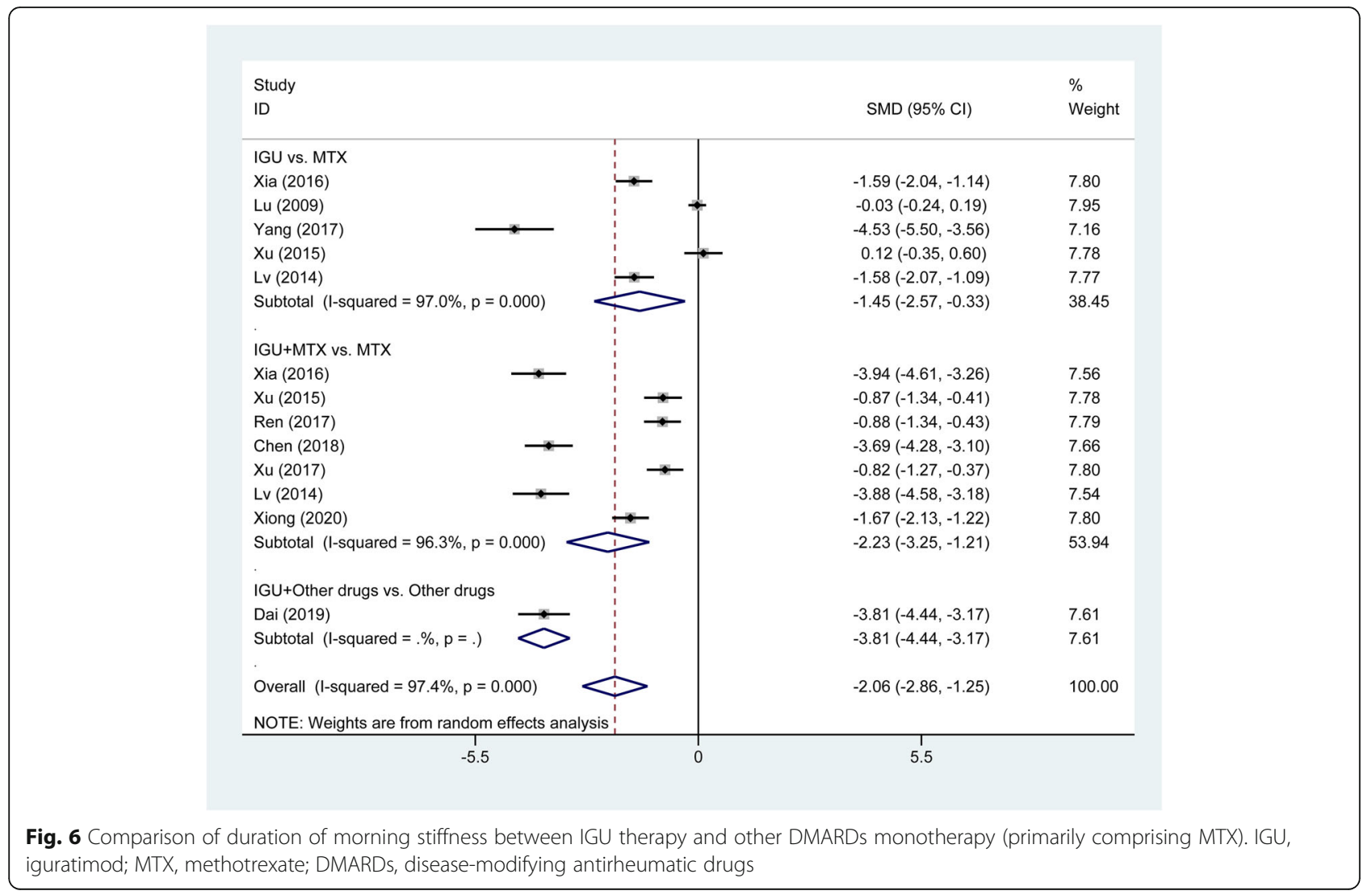

Fig. 7). In the subgroup analysis, both IGU monotherapy $(\mathrm{SMD}=-1.45,95 \% \mathrm{CI}-2.57$ to $-0.33, P=0.011)$ and IGU combined MTX therapy (SMD $=-2.23,95 \% \mathrm{CI}$ -3.25 to $-1.21, P<0.001)$ significantly shortened the duration of morning stiffness compared with MTX monotherapy (Fig. 6). The treatment of IGU plus leflunomide also significantly decreased the duration of morning stiffness compared with leflunomide monotherapy $(\mathrm{SMD}=-3.81,95 \% \mathrm{CI}-4.44$ to $-3.17, P<0.001)$. IGU monotherapy had similar reduction in HAQ score $(\mathrm{SMD}=0.18,95 \% \mathrm{CI}-0.07$ to $0.43, P=0.155)$, while IGU combined MTX therapy significantly decreased HAQ score compared with MTX monotherapy (SMD = $-1.91,95 \%$ CI -3.28 to $-0.53, P=0.007$; Fig. 7 ).

\section{Adverse events}

We combined data for adverse events including gastrointestinal reactions, leucopenia, increment in transaminase, increase of ALT, liver damage, and other adverse reactions. The meta-analysis of these adverse events was summarized in Table 2. Compared with MTX monotherapy, IGU monotherapy had comparable incidence of gastrointestinal reactions $(\mathrm{OR}=0.69,95 \% \mathrm{CI} 0.40$ to $1.04, P=0.070)$, leucopenia (OR $=0.69,95 \% \mathrm{CI} 0.34$ to $1.40, P=0.309)$, increment in transaminase $(\mathrm{OR}=2.7$, 95\% CI 0.38 to $19.09, P=0.321$ ), increase of ALT (OR =
$0.61,95 \%$ CI 0.38 to $1.00, P=0.051$ ), liver damage (OR $=0.13,95 \% \mathrm{CI} 0.01$ to $2.61, P=0.182)$ and fewer incidence of other adverse events (OR $=0.56,95 \%$ CI 0.33 to $0.95, P=0.032$ ). IGU combined MTX did not increase incidence of gastrointestinal reactions $(P=0.921)$, leucopenia $(P=0.838)$, increment in transaminase $(P=$ $0.193)$, increase of ALT $(P=0.985)$, and liver damage $(P$ $=0.123)$, but displayed a trend of increase in other adverse reactions compared with MTX monotherapy (OR $=2.42,95 \%$ CI 1.56 to $3.77, P<0.001)$.

\section{Analysis of sensitivity and publication bias}

The sensitivity analysis of ACR20 showed that the removing individual studies at one time alter the overall effect slightly (upper limit of 95\% CI interval lower than 3.53 in all cases, Supplementary Figure 1). The publication bias was estimated utilizing a funnel plot, which showed there was no evidence of asymmetry (Supplementary Figure 2). Furthermore, we performed an Egger test to quantify the publication bias, and the $P$ value was 0.898 , suggesting bias of the studies were non-existent.

\section{Discussion}

This systematic review of 23 RCTs demonstrated that IGU, as monotherapy or combination therapy, remarkable effectiveness, and good safety in the treatment of 


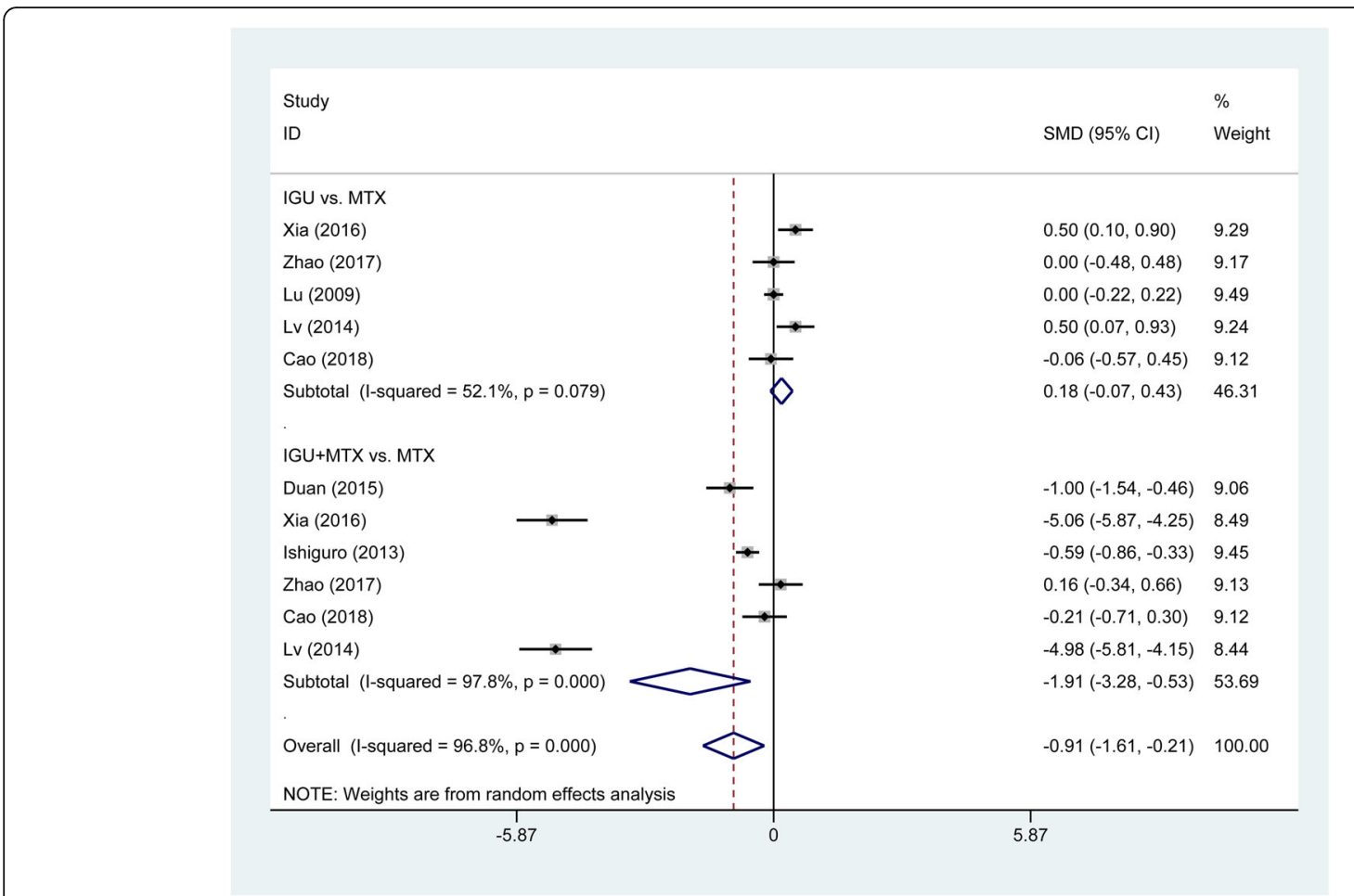

Fig. 7 Comparison of HAQ between IGU therapy and other DMARDs monotherapy (primarily comprising MTX). IGU, iguratimod; MTX, methotrexate; DMARDs, disease-modifying antirheumatic drugs

RA. Patients receiving IGU monotherapy or combined therapy demonstrated a greater reduction in DAS28CRP and DAS28-ESR than those with other DMARDs monotherapy (primarily comprising MTX). Regarding safety, IGU monotherapy or combined with other DMARDs therapy did not increase the risk of gastrointestinal reactions, leucopenia, increment in transaminase, increase of ALT, and liver damage compared to MTX monotherapy. Thus, taken together, these results indicated that IGU monotherapy or combined therapy may be a promising therapeutic strategy for RA.

\section{Efficacy}

IGU has been shown to display a comparable efficacy to MTX on RA amelioration when used as monotherapy. A phase III study comparing 2 initial doses of IGU to MTX in 489 RA patients revealed that IGU $50 \mathrm{mg} /$ day was equivalent to methotrexate in terms of ACR20 response $(63.8 \%$ vs. $62.0 \%)$ [18]. A recently published meta-analysis of 12 trials by Sajan Shrestha [24] demonstrated that IGU monotherapy has similar ACR 20 and HAQ, and better disease state, lower CRP level and ESR compared with other DMARDs therapy, which is basically consistent with our findings, indicating that IGU may be considered a potential alternative to MTX to treat RA. In clinical practice, combination of multiple antirheumatic drugs is usually required for RA treatment, since that the combination of IGU and other DMARDs, such as MTX, etanercept, and leflunomide have synergic efficacy for RA treatment. Our results showed that IGU plus MTX was more effective than the MTX monotherapy. A study by Hara et al. implied that improvement of IGU plus MTX therapy in ACR20 response could sustain through 52 weeks, and HAQ at week 52 significantly improved compared with the values at week 24 in the patients with active RA [48]. IGU combined etanercept (a biologic agent) [46] or leflunomide (an immunosuppressive agent) [45] was demonstrated to improve functional ability, and disease status of patients with RA at 12 weeks in terms of DAS 28-ESR.

\section{Pharmacological mechanism}

From a mechanistic view, therapeutic effects of IGU could be traced back to its anti-inflammatory, immunological action, and anabolic effects on bone metabolism. A preclinical study by Luo et al. found that the intervention of IGU plus MTX could remarkably inhibit infiltration of inflammatory cells into the synovium, and suppressed production of cytokines (IL-17, IFN- $\gamma$, IL-6, and TNF- $\alpha$ ) and antibodies (IgG and IgG2b) in serum in the mice with collagen-induced arthritis which is widely used in preclinical studies of RA [49]. Ishiguro et al. also revealed that treatment with IGU plus MTX significantly 
Table 2 The meta-analysis of the rate of adverse events of IGU monotherapy or combined therapy

\begin{tabular}{|c|c|c|c|c|c|c|}
\hline \multirow[t]{2}{*}{ Adverse reaction } & \multirow{2}{*}{$\begin{array}{l}\text { Comparison } \\
\text { (Drug } 1 \text { vs. Drug 2) }\end{array}$} & \multirow[t]{2}{*}{$\begin{array}{l}\text { Studies, } \\
n\end{array}$} & \multicolumn{2}{|c|}{$\begin{array}{l}\text { Participants, } \\
n\end{array}$} & \multirow[t]{2}{*}{ OR $(95 \% \mathrm{Cl}), P$ value } & \multirow[t]{2}{*}{$\begin{array}{l}\text { Test of heterogeneity } \\
\text { Cochran } Q, \mathrm{df}, P \text { value, } I^{2}\end{array}$} \\
\hline & & & $\begin{array}{l}\text { Drug } \\
1\end{array}$ & $\begin{array}{l}\text { Drug } \\
2\end{array}$ & & \\
\hline \multirow[t]{3}{*}{$\begin{array}{l}\text { Gastrointestinal } \\
\text { reactions }\end{array}$} & IGU vs. MTX & 7 & 356 & 359 & $\begin{array}{l}\mathrm{OR}=0.69(0.40,1.04), P= \\
0.070\end{array}$ & $\begin{array}{l}\text { Cochran } \mathrm{Q}=1.46, \mathrm{df}=6, P=0.962, P^{2}= \\
0.0 \%\end{array}$ \\
\hline & IGU+MTX vs. MTX & 13 & 540 & 534 & $\begin{array}{l}\mathrm{OR}=0.98(0.64,1.51), P= \\
0.921\end{array}$ & $\begin{array}{l}\text { Cochran } Q=5.72, \mathrm{df}=12, P=0.929, \rho^{2} \\
=0.0 \%\end{array}$ \\
\hline & $\begin{array}{l}\text { IGU+Other drugs vs. Other } \\
\text { drugs }\end{array}$ & 2 & 83 & 84 & $\begin{array}{l}\mathrm{OR}=1.43(0.28,7.45), P= \\
0.670\end{array}$ & $\begin{array}{l}\text { Cochran } Q=0.36, \mathrm{df}=1, P=0.547, P^{2}= \\
0.0 \%\end{array}$ \\
\hline \multirow[t]{2}{*}{ Leucopenia } & IGU vs. MTX & 8 & 406 & 409 & $\begin{array}{l}\mathrm{OR}=0.69(0.34,1.40), P= \\
0.309\end{array}$ & $\begin{array}{l}\text { Cochran } Q=3.39, \mathrm{df}=7, P=0.846, I^{2}= \\
0.0 \%\end{array}$ \\
\hline & IGU+MTX vs. MTX & 10 & 408 & 402 & $\begin{array}{l}\mathrm{OR}=0.93(0.48,1.80), P= \\
0.838\end{array}$ & $\begin{array}{l}\text { Cochran } Q=2.03, \mathrm{df}=9, P=0.991, P^{2}= \\
0.0 \%\end{array}$ \\
\hline \multirow[t]{3}{*}{$\begin{array}{l}\text { Increment in } \\
\text { transaminase }\end{array}$} & IGU vs. MTX & 2 & 52 & 58 & $\begin{array}{l}\mathrm{OR}=2.7(0.38,19.09), P= \\
0.321\end{array}$ & $\begin{array}{l}\text { Cochran } Q=0.01, \mathrm{df}=1, P=0.906, P^{2}= \\
0.0 \%\end{array}$ \\
\hline & IGU+MTX vs. MTX & 5 & 204 & 201 & $\begin{array}{l}\mathrm{OR}=1.90(0.72,4.99), P= \\
0.193\end{array}$ & $\begin{array}{l}\text { Cochran } Q=1.12, \mathrm{df}=4, P=0.891, I^{2}= \\
0.0 \%\end{array}$ \\
\hline & $\begin{array}{l}\text { IGU+Other drugs vs. Other } \\
\text { drugs }\end{array}$ & 1 & 54 & 54 & $\begin{array}{l}\mathrm{OR}=0.33(0.01,8.21), P= \\
0.497\end{array}$ & Cochran $Q=0.0, d f=0$ \\
\hline \multirow[t]{2}{*}{ Increase of ALT } & IGU vs. MTX & 3 & 249 & 247 & $\begin{array}{l}\mathrm{OR}=0.61(0.38,1.00), P= \\
0.051\end{array}$ & $\begin{array}{l}\text { Cochran } Q=1.95, \mathrm{df}=2, P=0.376, P^{2}= \\
0.0 \%\end{array}$ \\
\hline & IGU+MTX vs. MTX & 3 & 249 & 172 & $\begin{array}{l}\mathrm{OR}=0.99(0.50,1.97), P= \\
0.985\end{array}$ & $\begin{array}{l}\text { Cochran } Q=1.08, \mathrm{df}=2, P=0.583, P^{2}= \\
0.0 \%\end{array}$ \\
\hline \multirow[t]{2}{*}{ Liver damage } & IGU vs. MTX & 1 & 30 & 30 & $\begin{array}{l}\mathrm{OR}=0.13(0.01,2.61), P= \\
0.182\end{array}$ & Cochran $Q=0.0, d f=0$ \\
\hline & IGU+MTX vs. MTX & 3 & 129 & 129 & $\begin{array}{l}\mathrm{OR}=0.32(0.07,1.36), P= \\
0.123\end{array}$ & $\begin{array}{l}\text { Cochran } Q=0.00, \mathrm{df}=2, P=1.000, P^{2}= \\
0.0 \%\end{array}$ \\
\hline \multirow[t]{3}{*}{$\begin{array}{l}\text { Other adverse } \\
\text { reactions }\end{array}$} & IGU vs. MTX & 5 & 304 & 301 & $\begin{array}{l}\mathrm{OR}=0.56(0.33,0.95), P= \\
0.032\end{array}$ & $\begin{array}{l}\text { Cochran } Q=1.14, \mathrm{df}=4, P=0.888, I^{2}= \\
0.0 \%\end{array}$ \\
\hline & IGU+MTX vs. MTX & 12 & 614 & 532 & $\begin{array}{l}\mathrm{OR}=2.42(1.56,3.77), P< \\
0.001\end{array}$ & $\begin{array}{l}\text { Cochran } Q=17.74, \mathrm{df}=11, P=0.088, I^{2} \\
=38.0 \%\end{array}$ \\
\hline & $\begin{array}{l}\text { IGU+Other drugs vs. Other } \\
\text { drugs }\end{array}$ & 2 & 83 & 84 & $\begin{array}{l}\mathrm{OR}=1.02(0.14,7.42), P= \\
0.986\end{array}$ & $\begin{array}{l}\text { Cochran } Q=0.00, \mathrm{df}=1, P=0.986, P^{2}= \\
0.0 \%\end{array}$ \\
\hline
\end{tabular}

IGU iguratimod, MTX methotrexate, OR odd ratio

declined the rheumatoid factor $(33 \%, P<0.001)$, and immunoglobulins, such as IgA, IgM, and IgG levels $(P<$ 0.001 ) at 24 weeks in patients with RA, but these measures have no significantly change in the MTX group [20]. Dai et al. [45] found that IGU combined with leflunomide could significantly decreased serum inflammatory cytokines (TNF- $\alpha$, sTREM-1), and increase the level of bone metabolic markers (25(OH)D and TPINP) in patients of RA compared with etanercept monotherapy ( $P$ $<0.05$ ). Therefore, IGU may exert its clinical effect through an anti-inflammatory action, immunomodulatory action, and osteoprotective action in RA treatment.

\section{Adverse events}

The data of post-marketing surveillance involving 2666 patients showed that long-term treatment (52-week) with IGU resulted in a tolerable safety profile in patients with RA [50]. The incidences of serious AEs, and serious adverse drug reactions were $7.35 \%$ and $4.58 \%$, respectively. The adverse drug reactions appeared at approximately 4 weeks of treatment. Elevation of liver enzymes has been reported as a common adverse drug reaction of IGU. Treatment with IGU monotherapy $(50 \mathrm{mg} /$ day for 24 weeks or $25 \mathrm{mg} /$ day for the first 4 weeks and $50 \mathrm{mg} /$ day for the subsequent 20 weeks) result in fewer patients with increases of ALT in IGU group than in the MTX group $(13.5 \%$ or $6.1 \%$ vs $23.9 \%, P<0.05)$ [18]. Increases of ALT and AST were indicated to be similar at 24 weeks between combination therapy of IGU and MTX and MTX monotherapy (5.5\% vs $8.0 \%$ and $9.8 \%$ vs $5.7 \%$ ) [20]. This increase of liver enzymes was temporary, and patients would to recover during IGU treatment. Baseline liver dysfunction and low body weight were reported to be risk factors of liver dysfunction during IGU treatment [50]. In summary, IGU had a superior safety profile to MTX, and IGU combination did not increase 
incidence of AEs, which may be explained by multitarget mechanism of IGU. IGU targets upstream and downstream effectors of RA-related pathways, and did not effectively target a particular molecule. Thus, when IGU is used alone or in combination with MTX or other drugs to treat RA, its adverse events are tolerable, but patients still need to be closely monitored.

\section{Limitations}

The limitations of this study are as follows: (1) most RCTs included do not describe the details such as allocation concealment and blind method, and there may be bias in implementation and measurement; (2) at present, the clinical data are mainly from China and Japan, and there is a lack of population from other countries; (3) the included studies reported ACR20, DAS28, etc. which may be are approximations of disease progress. Some measures which can more exactly indicate the status of disease progress need to be developed. Therefore, it is recommended that multi-center, large-scale, strictly designed, randomized, double-blind clinical studies should be performed, and the data of international clinical studies should be collected in order to better evaluate the therapeutic effect of IGU.

\section{Conclusion}

Our analysis showed that the efficacy and safety of IGU in RA treatment was similar to that of MTX, and when combined with MTX or other DMARDs, the addition of IGU would have more benefits in terms of ACR20, DAS28-CRP, DAS28-ESR, and the duration of morning stiffness. Therefore, IGU has good efficacy and tolerance, and is a promising drug in clinical practice. IGU may be regarded as a potential alternative to MTX, and also a preferable choice when combined with other DMARDs for the treatment of RA. Large-scale and high-quality RCTs are necessary to further confirm our findings.

\section{Supplementary Information}

The online version contains supplementary material available at https://doi. org/10.1186/s13018-021-02603-2.

Additional file 1: Supplementary figure 1. Meta-analysis randomeffects estimates (linear form)

Additional file 2: Supplementary figure 2. Funnel plot with pseudo 95\% confidence limits

\section{Acknowledgements}

Not applicable.

\section{Authors' contributions}

Conception and design: Chao-Jun Hu, Li Zhang, and Jiu-Liang Zhao. Data collection: Chao-Jun Hu, Li Zhang, Shuang Zhou, Nan Jiang, and Qian Wang. Data analysis: Chao-Jun Hu, Li Zhang, and Jiu-Liang Zhao. Drafting article: Chao-Jun Hu and Li Zhang. Administrative support: Xin-Ping Tian and XiaoFeng Zeng. All the authors have read and approved the final manuscript.

\section{Funding}

This study was supported by 13th Five-Year National Science and Technology Major Project for New Drugs of the Ministry of Science and Technology of China (2019ZX09734001-002-004), the Chinese National Key Technology R\&D Program, Ministry of Science and Technology (2017YFC0907604), Medical and health Science and Technology Innovation Project of Chinese Academy of Medical Sciences (2019-12M-2-008), and Beijing Municipal Science \& Technology Commission (Z201100005520025)

Availability of data and materials

Not applicable.

\section{Declarations}

Ethics approval and consent to participate

Not applicable.

\section{Consent for publication}

Not applicable.

\section{Competing interests}

The authors have no conflicts of interest to declare.

Received: 2 March 2021 Accepted: 7 July 2021

Published online: 16 July 2021

References

1. Smolen JS, Aletaha D, Mclnnes IB. Rheumatoid arthritis. Lancet. 2016;388: 2023-38.

2. Becede M, Alasti F, Gessl I, Haupt L, Kerschbaumer A, Landesmann U, et al. Risk profiling for a refractory course of rheumatoid arthritis. Semin Arthritis Rheum. 2019;49:211-7

3. Chiu YM, Lang HC, Lin HY, Yang MT, Fang CH, Yang YW, et al. Risk of tuberculosis, serious infection and lymphoma with disease-modifying biologic drugs in rheumatoid arthritis patients in Taiwan. Int J Rheum Dis. 2014;17(Suppl 3):9-19.

4. Cavalli G, Favalli EG. Biologic discontinuation strategies and outcomes in patients with rheumatoid arthritis. Expert Rev Clin Immunol. 2019;15:131322.

5. Smolen JS, Landewe RBM, Bijlsma JWJ, Burmester GR, Dougados M, Kerschbaumer A, et al. EULAR recommendations for the management of rheumatoid arthritis with synthetic and biological disease-modifying antirheumatic drugs: 2019 update. Ann Rheum Dis. 2020;79:685-99.

6. Yuefeng C, Jianda M, Qianhua L, Lie D. The influence of biologics adherence on treating rheumatoid arthritis to target. J New Med. 2019:5:313-8.

7. $\mathrm{Xu} \mathrm{Y,} \mathrm{Zhu} \mathrm{Q,} \mathrm{Song} \mathrm{J,} \mathrm{Liu} \mathrm{H,} \mathrm{Miao} \mathrm{Y,} \mathrm{Yang} \mathrm{F,} \mathrm{et} \mathrm{al.} \mathrm{Regulatory} \mathrm{effect} \mathrm{of}$ iguratimod on the balance of Th subsets and inhibition of inflammatory cytokines in patients with rheumatoid arthritis. Mediat Inflamm. 2015;2015: 356040

8. Aikawa Y, Yamamoto M, Yamamoto T, Morimoto K, Tanaka K. An antirheumatic agent T-614 inhibits NF-kappaB activation in LPS- and TNF-alphastimulated THP-1 cells without interfering with IkappaBalpha degradation. Inflamm Res. 2002:51:188-94.

9. Du F, Lu LJ, Fu Q, Dai M, Teng JL, Fan W, et al. T-614, a novel immunomodulator, attenuates joint inflammation and articular damage in collagen-induced arthritis. Arthritis Res Ther. 2008;10:R136.

10. Jiang Y, Lu W, Yu SQ, Yao L, Xu GL, Zhang XR. Inhibitory effect of iguratimod on TNFalpha production and NF-kappaB activity in LPSstimulated rat alveolar macrophage cell line. Yao Xue Xue Bao. 2006:41:4015.

11. Tanaka K, Aikawa Y, Kawasaki H, Asaoka K, Inaba T, Yoshida C. Pharmacological studies on 3-formylamino - 7- methylsulfonylamino - 6 -phenoxy - 4H - 1 - benzopyran - 4 - one (T-614), a novel antiinflammatory agent. 4th communication: inhibitory effect on the production of interleukin-1 and interleukin-6. Aust J Pharm. 1992;15:649-55.

12. Luo Q, Sun Y, Liu W, Qian C, Jin B, Tao F, et al. A novel disease-modifying antirheumatic drug, iguratimod, ameliorates murine arthritis by blocking IL17 signaling, distinct from methotrexate and leflunomide. J Immunol. 2013; 191:4969-78.

13. Kong R, Gao J, Ji L, Peng Y, Zhang J, Zhao D. Iguratimod ameliorates rheumatoid arthritis progression through regulating miR-146a mediated 
IRAK1 expression and TRAF6/JNK1 pathway: an in vivo and in vitro study. Clin Exp Rheumatol. 2020;39(2):289-303.

14. Song J, Liu H, Zhu Q, Miao Y, Wang F, Yang F, et al. T-614 promotes osteoblastic cell differentiation by increasing D|x5 expression and regulating the activation of p38 and NF-kappaB. Biomed Res Int. 2018;2018:4901591.

15. Du F, Lu LJ, Teng JL, Shen N, Ye P, Bao CD. T-614 alters the production of matrix metalloproteinases (MMP-1 andMMP-3) and inhibits the migratory expansion of rheumatoid synovial fibroblasts, in vitro. Int Immunopharmacol. 2012;13:54-60.

16. Wang XT, Li P, Xu TS, Ding R, Zhang X, Bi LQ. Effect of iguratimod and methotrexate on RANKL and OPG expression in serum and IL-1 betainduced fibroblast-like synoviocytes from patients with rheumatoid arthritis. Cell Mol Biol. 2016;62:44-50.

17. Kuriyama K, Higuchi C, Tanaka K, Yoshikawa H, Itoh K. A novel antirheumatic drug, T-614, stimulates osteoblastic differentiation in vitro and bone morphogenetic protein-2-induced bone formation in vivo. Biochem Biophys Res Commun. 2002;299:903-9.

18. Lu L, Bao CD, Dai M, Teng JL, Fan W, Du F, et al. Multicenter, randomized, double-blind, controlled trial of treatment of active rheumatoid arthritis with T-614 compared with methotrexate. Arthritis Rheum. 2009;61:979-87.

19. Xia Z, Lyu J, Hou N, Song L, Li X, Liu H. Iguratimod in combination with methotrexate in active rheumatoid arthritis: therapeutic effects. $Z$ Rheumatol. 2016;75:828-33.

20. Ishiguro N, Yamamoto K, Katayama K, Kondo M, Sumida T, Mimori T, et al. Concomitant iguratimod therapy in patients with active rheumatoid arthritis despite stable doses of methotrexate: a randomized, double-blind, placebocontrolled trial. Mod Rheumatol. 2013;23:430-9.

21. Lau CS, Chia F, Harrison A, Hsieh TY, Jain R, Jung SM, et al. APLAR rheumatoid arthritis treatment recommendations. Int J Rheum Dis. 2015;18: 685-713.

22. Lau CS, Chia F, Dans L, Harrison A, Hsieh TY, Jain R, et al. 2018 update of the APLAR recommendations for treatment of rheumatoid arthritis. Int J Rheum Dis. 2019;22:357-75.

23. Chinese Rheumatology A. 2018 Chinese guideline for the diagnosis and treatment of rheumatoid arthritis. Zhonghua Nei Ke Za Zhi. 2018;57:242-51.

24. Shrestha S, Zhao J, Yang C, Zhang J. Relative efficacy and safety of iguratimod monotherapy for the treatment of patients with rheumatoid arthritis: a systematic review and meta-analysis. Clin Rheumatol. 2020:39: 2139-50.

25. Arnett FC, Edworthy SM, Bloch DA, McShane DJ, Fries JF, Cooper NS, et al. The American Rheumatism Association 1987 revised criteria for the classification of rheumatoid arthritis. Arthritis Rheum. 1988:31:315-24.

26. Aletaha D, Neogi T, Silman AJ, Funovits J, Felson DT, Bingham CO 3rd, et al. 2010 Rheumatoid arthritis classification criteria: an American College of Rheumatology/European League Against Rheumatism collaborative initiative. Arthritis Rheum. 2010;62:2569-81.

27. Higgins JP, Altman DG, Gøtzsche PC, Jüni P, Moher D, Oxman AD, et al. The Cochrane Collaboration's tool for assessing risk of bias in randomised trials. BMJ. 2011;343:d5928.

28. Zhao $L$, Jiang $Z$, Zhang $Y, M a ~ H, C a i ~ C$. Analysis of efficacy and safety of treatment of active rheumatoid arthritis with iguratimod and methotrexate; 2017.

29. Zhao W, Yao D, Huo H, Qin C, Wei Q, Sun K. Clinical study of iguratimod in the treatment of active rheumatoid arthritis. Chin J Postgrad Med. 2016;39: 450-2.

30. Xiong YM, Fan S, Zou L. A clinical study of iguratimod combined with methotrexate on the effect of anti-cyclic citrullinated peptide antibody and other outcomes in patients with rheumatoid arthritis. J Clin Intern Med. 2015;32:833-5

31. Yang $H$, Lin $\mathrm{S}$, Yang $\mathrm{H}$, Xie X, Wang X. Effect of Iguratimod on the vascular endothelial growth factor and pigment epithelial-derived factor in patients with rheumatoid arthritis. Chin J Clin Pharmacol Ther. 2017;22:68-71.

32. Cao L, Yin $\mathrm{H}, \mathrm{Li}$, Wang $\mathrm{H}$, Yin $\mathrm{S}$. The study of iguratimod on clinical effect and bone metabolism in patients with elderly-onset rheumatoid arthritis. Chin J Gerontol. 2018;38:5500-2.

33. Xu B, Mo $S$, Xue X. Clinical effect of methotrexate combined with iguratimod on treatment of rheumatoid arthritis. J Clin Med Pract. 2015;19: $120-2$.

34. Hui-Ling H. Clinical effect and safety of iguratimod for treating rheumatoid arthritis. Master, Soochow University; 2014.
35. LV J. The therapeutic effects of a combination of iguratimod and methotrexate on active rheumatoid arthritis. 硕士, Shandong University: 2014.

36. Duan XW, Zhang XL, Mao SY, Shang JJ, Shi XD. Efficacy and safety evaluation of a combination of iguratimod and methotrexate therapy for active rheumatoid arthritis patients: a randomized controlled trial. Clin Rheumatol. 2015;34:1513-9.

37. Yanhong REN, Wei DO, Hua LIU, Lu LIU. Clinical observation of iguratimod combined with methotrexate in the treatment of rheumatoid arthritis. China Pharm. 2017;28:4530-3.

38. Wang S. Observation of the effect of iguratimod combined with MTX on rheumatoid arthritis. J Bethune Mil Med Coll. 2017;15:309-11.

39. Bai Q. Clinical study of iguratimod combined with methotrexate in the treatment of active rheumatoid arthritis. Med Inf. 2015;28:118-9.

40. Li Xie QZ, Shi Y, Cheng X, Fang Y. Effect of iguratimod combined with MTX on the levels of IL-1, serum TNF- $a$ and VEGF in patients with refractory rheumatoid arthritis. Guizhou Medi J. 2018;42:831-2.

41. Wang Z. Efficacy and safety analysis of combination of methotrexate and iguratimod in the treatment of refractory rheumatoid arthritis. Chinese J Mod Drug Appl. 2016;10:105-6.

42. Meng Degian PW, Ju L, Hui LI, Fang LI, Shanshan LIU, Yongsheng LI, et al. Effect of methotrexate combined with iguratimod in the treatment of patients with refractory rheumatoid arthritis. China Med Herald. 2016;13: 137-41.

43. Chen J, ZD, Liu J. The effect of iguratimod combined with methotrexate on serum inflammatory factors and bone metabolism in patients with rheumatoid arthritis. Zhejiang J Integr Tradit Chin West Med. 2018;28:552-5.

44. Li-Ming XU, YM, Yi-Fan LIU, Huan-Xia SUN, Li-Ning LIU, Yan-Jun SHI, et al. Clinical observation of limonoid combined with methotrexate in the treatment of rheumatoid arthritis. Guide China Med. 2017:15:47-8.

45. Lu D, SX, Xiaoming Q, Wenting Z, Yao S, Yangjie L. Efficiency observation of iguratimod combined with leflunomide on the treatment of elderly patients with moderate and severe active rheumatoid arthritis. J Clin Med Pract. 2019;23:73-7.

46. Xuerong L, CY, Bangshuo Z, Jing C, Hui X, Sheng W, et al. The effect of Iguratimod combined with etanercept on CD4+, CD8+T cells and immunoglobulin of patients with refractory rheumatoid arthritis. Immunol J. 2018;34:141-5.

47. Xiong $M$, Geng $G$. Clinical effect of methotrexate combined with iguratimod on active rheumatoid arthritis. Henan Med Res. 2020;1:93-5.

48. Hara M, Ishiguro N, Katayama K, Kondo M, Sumida T, Mimori T, et al. Safety and efficacy of combination therapy of iguratimod with methotrexate for patients with active rheumatoid arthritis with an inadequate response to methotrexate: an open-label extension of a randomized, double-blind, placebo-controlled trial. Mod Rheumatol. 2014;24:410-8.

49. Luo Q, Sun Y, Jin B, Zheng W, Shao F, Hang N, Shu Y, et al. lguratimod synergizes with methotrexate to exert anti-inflammatory and boneprotective effect and block the progression of collagen-induced arthritis in mice. Biochem Pharmacol. 2014;3(3):135.

50. Mimori T, Harigai M, Atsumi T, Fujii T, Kuwana M, Matsuno H, et al. Safety and effectiveness of iguratimod in patients with rheumatoid arthritis: final report of a 52-week, multicenter postmarketing surveillance study. Mod Rheumatol. 2019;29:314-23.

\section{Publisher's Note}

Springer Nature remains neutral with regard to jurisdictional claims in published maps and institutional affiliations.

\section{Ready to submit your research? Choose BMC and benefit from}

- fast, convenient online submission

- thorough peer review by experienced researchers in your field

- rapid publication on acceptance

- support for research data, including large and complex data types

- gold Open Access which fosters wider collaboration and increased citations

- maximum visibility for your research: over $100 \mathrm{M}$ website views per year

At $\mathrm{BMC}$, research is always in progress.

Learn more biomedcentral.com/submissions 